\title{
Response of Rainbow Trout Immunized with Formalin-killed Vibrio anguillarum: Activity of Phagocytosis of Fish Macrophages and Opsonizing Effect of Antibody
}

\author{
Akihiko Honda, Hiroshi Kodama, Mohamed Moustafa, \\ Fumitaka Yamada, Takeshi Mikami, \\ and Hisao IzawA
}

Department of Epizootiology, Faculty of Veterinary Medicine, Hokkaido University, Sapporo 060, Japan

\begin{abstract}
To know the host defense mechanism against infection with Vibrio anguillarum in rainbow trout, phagocytic activities of macrophages were examined with those collected from normal fish and fish immunized with formalin-killed $V$. anguillarum. Opsonic activity with specific antibody and complement was also investigated. Forty to $50 \%$ of the macrophages of peritoneum, pronephron and peripheral blood phagocytosed latex particles. The phagocytosis of $V$. anguillarum by normal peritoneal macrophages was enhanced in the presence of antibody and complement. Enhanced opsonization was also observed after treatment of either macrophages or bacteria with antibody. In rainbow trout immunized with $V$. anguillarum, phagocytic activity of macrophages increased significantly 5 weeks after immunization as compared to the activity of macrophages from normal fish. The agglutinin titers increased 3 weeks after immunization. However, bactericidal activity of antibody and complement was not detected in the present experiment. All 8 rainbow trout were protected from infection with the bacteria 5 weeks after immunization and 7 out of 10 fish challenged 1 week after immunization survived. These results indicate that immunized fish were able to develop protective immunity against Vibrio infection before significant levels of antibody or phagocytic activity become detectable.
\end{abstract}

\section{Introduction}

The host defense mechanisms mediated by the phagocytic and bactericidal activities of macrophages against various pathogenic microorganisms have been extensively investigated in mammalian and avian species. In the process of phagocytosis of bacteria, specific antibody plays a role as opsonin by coating the surface of antigen and making the antigen more susceptible to phagocytosis (WeIR, 1973). IgM antibodies perform this role particularly efficiently. Furthermore, it is known that complements also act as opsonins in promoting phagocytosis.

In fish, phagocytosis of foreign antigenic material has also been considered as a non-specific host defense mechanism and as an initial step in triggering the immune response (AvTALION and Shahrabani, 1975; Braun-Nesje et al., 1981; FinN and Nielson, 1971; Gontcharov and Mikriakov, 1968; GrifFIN, 1983; MCKINNEY et al., 1977; SAKAI,
1984; Wrathwell and Parish, 1981). However, only few information are available on the effects of immunization on the phagocytosis and/or intracellular killing of bacteria in vivo and in vitro (Avtalion and Shahrabani, 1975; Gontcharov and MiKriaKov, 1968; SAKAI, 1984), and on the role of antibody and complement in phagocytosis of bacteria (Griffin, 1983; SAKAI, 1984; WrathWELL and PARISH, 1981). The purpose of the present study was to know the host defense mechanism by examining the opsonic activity of specific antibody and complement and the phagocytic activity of rainbow trout macrophages collected from normal fish and fish immunized with formalin-killed Vibrio anguillarum.

\section{Materials and Methods}

Fish

Rainbow trout were purchased from a commercial fish farm. Fish weighing 50 to $80 \mathrm{~g}$ were 
used for collection of peritoneal exudate cells (PEC) and complement, and experimental infection with $V$. anguillarum. Fish weighing 500 to $1000 \mathrm{~g}$ were used for immunization and collection of anti- $V$. anguillarum serum. Fish were acclimatized to laboratory conditions for several weeks in 50-liter plastic aquaria filled with ground water (flow rate 0.5 liter $/$ minute, $12^{\circ} \mathrm{C}$ ).

\section{Bacteria}

Virulent strain of $V$. anguillarum (NCMB571 strain) was obtained through the courtesy of $\mathrm{Mr}$. I. Komatsu (Central Laboratories, Kyoritsu Shoji Co., Ltd., Ibaraki, Japan). The bacteria were passaged once in rainbow trout. The $50 \%$ lethal dose $\left(\mathrm{LD}_{50}\right)$ of the bacteria, calculated by the method of BEHRENS-KäRBER (KÄRBER, 1931), was $2.1 \times$ $10^{4}$ when inoculated intrapertioneally into rainbow trout weighing $15 \mathrm{~g}$. The bacteria were grown for 24 hours at $25^{\circ} \mathrm{C}$ in heart infusion (HI) broth (Nissui Seiyaku Co., Tokyo, Japan) containing $1.5 \% \mathrm{NaCl}$.

\section{Formalin-killed Bacteria}

$V$. anguillarum cultivated in $\mathrm{HI}$ broth were washed 3 times by centrifugation $(4900 \times g$, 20 minutes) and suspended in phosphate buffered saline (PBS, pH 7.2, 0.15 M). Formaldehyde solution was added to a final concentration of $0.3 \%$ and the bacteria was inactivated overnight at $25^{\circ} \mathrm{C}$ with occasional shaking. After removing formalin by centrifugation, $10 \%$ bacterial suspension was prepared in PBS. Lack of bacterial growth was confirmed by inoculation of the suspension onto HI agar.

\section{Antiserum and Complement}

Anti- $V$. anguillarum rainbow trout serum was prepared by immunization of fish with formalinkilled bacteria. The bacterial suspension was diluted 200 times in PBS and emulsified with an equal volume of Freund's complete adjuvant (Difco, Detroit, Mich.). Rainbow trout were inoculated intraperitoneally with $1 \mathrm{~m} l$ of the antigen. Booster injections were given 2 and 3 weeks later with the antigen without adjuvant. After antibody titers determined by agglutination test increased sufficiently, blood was collected and sera were stored at $-20^{\circ} \mathrm{C}$ or $-80^{\circ} \mathrm{C}$. If necessary, the sera were inactivated at $44^{\circ} \mathrm{C}$ for 20 minutes as described by

\section{SAKaI (1981).}

Blood collected from normal rainbow trout was allowed to stand at room temperature for several minutes, and centrifuged at $1000 \times g$ for 5 minutes at $4^{\circ} \mathrm{C}$. The sera obtained from several fish were pooled and used as complement without storage.

\section{Peritoneal Exudate Cells (PEC) and Glass-Adherent Cells}

Rainbow trout were injected intraperitoneally with liquid paraffin (Kanto Chemical Co., Tokyo, Japan) $(0.5 \mathrm{~m} /), 3 \%$ sodium thioglycolate (Kanto Chemical Co.) $(1 \mathrm{~m} /)$, mixture of $5 \%$ polypeptone (Daigo Eiyo Kagaku Co., Tokyo, Japan) and 5\% soluble starch (Kanto Chemical Co.) $(1 \mathrm{ml})$, or $8 \%$ casein sodium (Wako Pure Chemical, Tokyo, Japan) $(1 \mathrm{~m} l)$. PEC inducers other than liquid paraffin were suspended in PBS. PEC were collected 3 days after the injection unless otherwise indicated. After anaesthetization with m-aminobenzonic acid ethylester methanesulphonate solution (100 ppm) (MS222; Sankyo Co., Tokyo, Japan) blood was withdrawn from the caudal vessel by syringe to avoid contamination of blood cells in PEC preparation. The peritoneal cavity was washed carefully with $12 \mathrm{ml}$ of ice cold Hank's solution (Nissui Seiyaku Co.) ( $\mathrm{pH}$ 7.2) containing 1000 units of penicillin, $1000 \mu \mathrm{g}$ of streptomycin and $5 \mu \mathrm{g}$ of fungizone per $\mathrm{m} l$. The cells were washed 3 times by centrifugation $\left(120 \times g, 5\right.$ minutes, $\left.4^{\circ} \mathrm{C}\right)$ in siliconized plastic tubes, and then suspended in Eagle's minimum essential medium (MEM, Nissui Seiyaku Co.) (pH 7.2) supplemented with $10 \%$ fetal bovine serum (FBS) and antibiotics (200 units of penicillin, $200 \mu \mathrm{g}$ of streptomycin and $2.5 \mu \mathrm{g}$ of fungizone $/ \mathrm{m} l$ ) at a concentration of $3 \times 10^{5}$ viable cells $/ \mathrm{m} l$. Viability of the cells was determined by trypan blue dye exclusion test. The PEC were seeded into 24well plastic plate $(1 \mathrm{~m} / /$ well) (Nunc, Roskilde, Denmark) containing round cover glass in each well and were cultivated at $20^{\circ} \mathrm{C}$ in a humidified incubator supplemented with $5 \% \mathrm{CO}_{2}$. After 6 days, supernatant and non-glass-adherent cells were removed. After washing the wells with MEM, cells that remained adherent to cover glasses were used for experiments as glass-adherent cells.

Preparation of Macrophage-like Cells from Peripheral Blood Leukocytes and Pronephron Cells The macrophage-like cells were prepared from 
pronephron and peripheral blood of fish by discontinuous Percoll gradient density centrifugation as reported by BRAUN-NeSJE et al. (1981). Pronephron cells were obtained by mincing the pronephrons and then filtrating through stainless-steel mesh (size 200gauge). Buffy coat cells were obtained by centrifugation at $1000 \times g$ for 10 minutes of the heparinized blood collected from fish. These cells were washed with MEM by centrifugation. On the bottom layer of $3.5 \mathrm{~m} /$ Percoll (Pharmacia, Uppsala, Sweden) diluted in PBS to a final density of 1.100 $2 \mathrm{~m} l$ of Percoll diluted in PBS to a final density of 1.080 was overlayed. Two $\mathrm{m} l$ of Percoll diluted in MEM without FBS to a final density of 1.070 were layered over the second Percoll layer. Finally $3.5 \mathrm{ml}$ of cell suspension in MEM supplemented with FBS were carefully layered at the top. The tubes were centrifuged at $800 \times g$ for 60 minutes at $4^{\circ} \mathrm{C}$. The band formed at a density of 1.070 , which contained macrophage-like cells was collected and washed with MEM. The cells were cultivated for 6 days to obtain glass-adherent cells as described previously.

\section{Phagocytic Activity of Glass-Adherent Cells}

Phagocytic activity of glass-adherent cells was evaluated as follows. Suspensions of latex particles $\left(2 \times 10^{8} \mathrm{cells} / \mathrm{m} / /\right.$ well) (Latex 0.81 , Difco) or bacterial cell suspension $\left(2 \times 10^{5}, 2 \times 10^{6}\right.$ or $2 \times$ $10^{7} \mathrm{cell} / \mathrm{s} / \mathrm{m} / /$ well) in MEM containing $10 \%$ FBS without antibiotics were added to each well of plastic plates containing cover glass. If necessary, inactivated anti- $V$. anguillarum rainbow trout serum diluted to final agglutinin titers of 0.15 to $30 \mathrm{~m} l$ and rainbow trout complement at concentrations of 0.4 to $20 \%$ were supplemented to the medium. After incubation at $20^{\circ} \mathrm{C}$ for 60 minutes, cover glasses were removed and extensively washed with PBS, and then stained with May-Giemsa. The percentage of glass-adherent cells that phagocytosed latex particles or bacteria, and the number of latex particles or bacteria in each cell were determined under a microscope observing 400 cells per cover glass.

To examine the mechanism of opsonic effect of antibody, either glass-adherent cells or $V$. anguillarum were pretreated with anti- $V$. anguillarum rainbow trout serum. The serum diluted with medium to an agglutinin titer to $30 \mathrm{ml}$ was added to glass-adherent cell cultures. After incubation at $37^{\circ} \mathrm{C}$ for 60 minutes, cells were washed 3 times with fresh medium without rainbow trout serum. For the treatment of $V$. anguillarum, bacteria were suspended in medium containing antiserum and incubated at $20^{\circ} \mathrm{C}$ for 60 minutes. Cells were washed once with fresh medium by centrifugation at $1250 \times g$ for 20 minutes at $4^{\circ} \mathrm{C}$. Bacteria untreated or treated with the antiserum $\left(2 \times 10^{7}\right.$ cells $\left./ \mathrm{m} l\right)$ was added to normal glass-adherent cells or cells treated with the antiserum. To control cultures were added $1 \mathrm{~m} /$ of untreated bacteria $\left(2 \times 10^{7}\right.$ cells) suspended in medium with or without rainbow trout antiserum.

\section{Immunization of Rainbow Trout with Formalin- killed V. anguillarum and Challenge with Living Bacteria}

A group of rainbow trout were immunized intraperitoneally with $0.5 \mathrm{~m} l$ emulsion of formalinkilled bacteria and adjuvant. The phagocytic activity of glass-adherent cells of PEC from fish which had been immunized 1, 3 and 5 weeks before and injected with $8 \%$ casein sodium 3 days before were examined. In each experiment, 5 fish were used and blood was withdrawn before the collection of PEC. Control fish injected with the adjuvant were simultaneously bled and PEC were also collected from them. Some of the immunized and control rainbow trout were challenged intraperitoneally with $10^{8}$ cells $/ 0.1 \mathrm{~m} /$ of $V$. anguillarum at 1 or 5 weeks after immunization and observed for 14 days.

\section{Bactericidal Test}

To a suspension of viable $V$. anguillarum $\left(2.0 \times 10^{6} \mathrm{cells} / 0.2 \mathrm{~m} l\right)$ was added $0.4 \mathrm{~m} l$ of inactivated rainbow trout serum from immunized or normal fish, $0.4 \mathrm{~m} l$ of pooled fresh rainbow trout serum and $1.0 \mathrm{~m} /$ of $\mathrm{HI}$ broth. The mixture was incubated at $20^{\circ} \mathrm{C}$ for 60 minutes then the number of viable bacteria was estimated according to the method of MiLES and MisRa (1938), using HI agar plates. The percentage of surviving bacteria was calculated according to the formula,

$\%$ surviving bacteria

$$
=\frac{\text { Number of bacteria after incubation }}{\text { Number of bacteria before incubation }} \times 100
$$

\section{Agglutination Test}

Agglutinin titers of sera were determined according to the method of ANTIPA and AMEND (1977). 
Antisera were diluted 2-fold in PBS in 96-well microplate (Falcon, Oxnard, Calif.). To $0.025 \mathrm{~m} /$ of each dilution, $0.025 \mathrm{~m} l$ of $0.5 \%$ suspension of formalin-killed bacteria was added and the plate was left overnight at $4^{\circ} \mathrm{C}$. Agglutinin titer was expressed as the reciprocal of the highest dilution of serum that caused agglutination of the bacteria.

\section{Statistics}

Students $t$-test was used.

\section{Results}

\section{Induction of PEC}

Rainbow trout PEC was collected 2 to 4 days after inoculation of inducers such as liquid paraffin, casein sodium, thioglycolate or a mixture of polypeptone and soluble starch. The percentage of glass-adherent cells in PEC was estimated after cultivation of PEC for 1 week. The yield of PEC from fish preinoculated with polypeptone + soluble starch or with casein sodium was more than $10^{6}$ cells/fish and usually 60 to $80 \%$ of the PEC were glass adherent (Table 1). On the other hand, the number of PEC induced by liquid paraffin was less than $10^{6}$ cells/fish and the percentage of glass-adherent cells was usually low. Fish inoculated with $3 \%$ sodium thioglycolate died of toxicity.

\section{Phagocytic Activity of Glass-Adherent Cells}

The phagocytic activities of glass-adherent cells from PEC, pronephron cells and peripheral blood against latex particles were examined. Glass-adherent cells from PEC induced by polypeptone + soluble starch had higher phagocytic activity than those from PEC induced by casein sodium or from pronephron and peripheral blood (Table 2).

Based on the results showed in Tables 1 and 2, PEC collected 3 days after the inoculation of $8 \%$

Table 1. Induction of peritoneal exudate cells of rainbow trout

\begin{tabular}{lccc}
\hline \multirow{2}{*}{ Inducer } & \multicolumn{2}{c}{ Days peritoneal exudate cells collected } \\
\cline { 2 - 4 } & 2 days & 3 days & 4 days \\
\hline Liquid paraffin & $\begin{array}{c}5.3 \pm 4.8 \times 10^{41)} \\
(46.4 \pm 3.8)^{2)}\end{array}$ & $\begin{array}{c}7.5 \pm 5.3 \times 10^{5} \\
(51.0 \pm 3.7)\end{array}$ & $\begin{array}{c}9.5 \pm 3.5 \times 10^{5} \\
(56.0 \pm 5.7)\end{array}$ \\
$5 \%$ polypeptone $+5 \%$ soluble starch & $\begin{array}{c}3.3 \pm 0.7 \times 10^{6} \\
(61.0 \pm 2.2)\end{array}$ & $\begin{array}{c}2.8 \pm 1.0 \times 10^{6} \\
(65.0 \pm 2.9)\end{array}$ & $\begin{array}{c}2.6 \pm 1.0 \times 10^{6} \\
(72.7 \pm 10.2)\end{array}$ \\
$8 \%$ casein sodium & $\begin{array}{c}3.5 \pm 1.4 \times 10^{6} \\
(45.3 \pm 4.9)\end{array}$ & $\begin{array}{c}3.4 \pm 1.3 \times 10^{6} \\
(73.3 \pm 0.7)\end{array}$ & $\begin{array}{c}2.0 \pm 0.7 \times 10^{6} \\
(80.0 \pm 6.4)\end{array}$ \\
\hline
\end{tabular}

1) Number of peritoneal exudate cells/fish (mean value \pm SD from 3 rainbow trout).

2) Mean $\% \pm \mathrm{SD}$ of glass-adherent cells.

Table 2. Phagocytic activity of glass-adherent cells against latex particles

\begin{tabular}{|c|c|c|c|}
\hline \multirow{2}{*}{ Glass-adherent cells } & \multicolumn{3}{|c|}{ Number of latex particles phagocytosed by cells } \\
\hline & $\geqq .5$ & $1-4$ & 0 \\
\hline $\begin{array}{l}\text { Peritoneal exudate cells }{ }^{1)} \\
\qquad(8 \% \text { casein sodium })\end{array}$ & $5.3 \pm 0.7^{2)}$ & $35.2 \pm 1.0$ & $59.6 \pm 0.5$ \\
\hline $\begin{array}{l}\text { Peritoneal exudate cells } \\
\quad(5 \% \text { polypeptone }+5 \% \text { soluble starch })\end{array}$ & $15.0 \pm 1.8$ & $25.3 \pm 1.4$ & $59.7 \pm 3.1$ \\
\hline Pronephron & $5.0 \pm 0.2$ & $49.3 \pm 4.2$ & $45.6 \pm 4.1$ \\
\hline Peripheral blood & $9.7 \pm 1.9$ & $39.7 \pm 3.9$ & $50.7 \pm 2.1$ \\
\hline
\end{tabular}

1) Collected 3 days after the inoculation of PEC inducer.

2) Percentage of glass adherent cells containing certain numbers of latex particles (mean value $\pm \mathrm{SD}$ from 3 separate experiments). 
Table 3. Phagocytic activity of peritoneal macrophages of rainbow trout against Vibrio anguillarum in the presence of specific antibody

\begin{tabular}{ccc}
\hline \multirow{2}{*}{$\begin{array}{c}\text { Antibody (agglutinin) } \\
\text { titer }{ }^{1)}\end{array}$} & \multicolumn{2}{c}{ Phagocytic activity } \\
\cline { 2 - 3 } & $2 \times 10^{\left.7^{2}\right)}$ & $2 \times 10^{6}$ \\
\hline \multirow{2}{*}{30} & $12.0 \pm 2.7^{3)}$ & $6.1 \pm 1.6$ \\
& $(p<0.02)$ & $(p<0.02)$ \\
15 & $11.0 \pm 2.0$ & $4.9 \pm 0.5$ \\
1.5 & $(p<0.02)$ & $(p<0.05)$ \\
0.15 & $7.4 \pm 2.8$ & $4.6 \pm 2.1$ \\
& $6.4 \pm 1.2$ & $2.2 \pm 0.6$ \\
Normal rainbow trout serum & $6.2 \pm 1.3$ & $1.5 \pm 0.4$ \\
$(10 \%)$ & & \\
Without serum & $5.2 \pm 0.8$ & $1.8 \pm 0.5$ \\
\hline
\end{tabular}

1) Anti- $V$. anguillarum rainbow trout serum diluted with medium to respective titers as indicated.

2) Number of bacteria added/well.

3) Mean \pm SD of macrophage which phagocytosed more than 5 bacteria from 3 separate experiments.

casein sodium was used in the following experiments.

\section{Opsonization by Antiserum and Complement}

Opsonizing effect of anti- $V$. anguillarum rainbow trout serum was examined. $V$. anguillarum $\left(2 \times 10^{7}\right.$ or $2 \times 10^{6}$ cells) were ingested by glass-adherent cells in the presence of antiserum diluted to the agglutinin titers of 0.15 to $30 /$ well. The result showed that opsonizing effects of the serum increased with increasing amount of antibody in cultures (Table 3). Phagocytic activity (percentage of cells that phagocytosed more than 5 bacteria) increased significantly in the presence of antibody with titers of 15 and 30/well.

The effect of rainbow trout complement on the phagocytosis of $V$. anguillarum was tested by mixing $1 \mathrm{~m} l$ of medium containing various amounts of antiserum and complement, and a constant number of the bacteria $\left(2 \times 10^{7}\right.$ cells $)$. The results indicated that rainbow trout complement enhanced the opsonizing effect of antibody (Fig. 1). In the presence of anti- $V$. anguillarum serum with agglutinin titers of 15 or 30 in the test system, $9.8 \%$ of glass adherent cells phagocytosed more than 5 bacteria in the absence of complement, whereas over $16.0 \%$ of the cells phagocytosed them in the presence of $20 \%$ complement. However, complement did not reveal

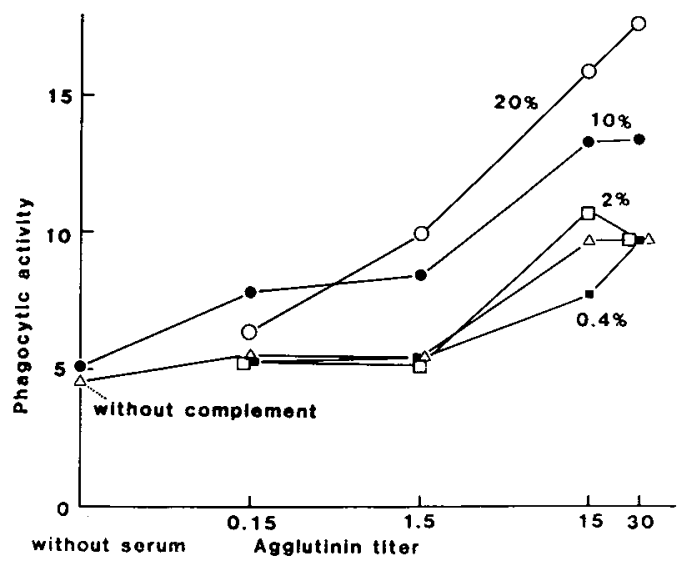

Fig. 1. Effect of rainbow trout complement on the phagocytosis of $V$. anguillarum. $2 \times 10^{7}$ bacterial cells were phagocytosed by glass-adherent cells in the presence of complement $(0.4$ to $20 \%)$ and antiserum (agglutinin titers of 0.15 to $30 / \mathrm{m} l)$.

Table 4. Effect of treatment of peritoneal macrophages or Vibrio anguillarum with anti- $V$. anguillarum rainbow trout serum on phagocytic activity of macrophages

\begin{tabular}{lc}
\hline \hline Treatment with antiserum & Phagocytic activity \\
\hline Treatment of macrophage & $18.7 \pm 3.6^{1)}(p<0.001)$ \\
Treatment of bacteria & $14.4 \pm 4.5 \quad(p<0.001)$ \\
Addition of antiserum & $15.1 \pm 2.4 \quad(p<0.001)$ \\
$\quad$ in medium & $5.2 \pm 1.4$ \\
Untreated &
\end{tabular}

1) Mean $\% \pm \mathrm{SD}$ of macrophage which phagocytosed more than 5 -bacteria in the presence of rainbow trout complement $(20 \%)$ from 3 separate experiments.

any opsonizing effect by itself at a concentration of $10 \%$.

To know the mechanism of opsonizing effect by antiserum, either glass-adherent cells or $V$. anguillarum were treated with the antiserum before phagocytosis. The result indicated that treatment of glass-adherent cells as well as of $V$. anguillarum with antiserum resulted in significant increase of the phagocytic activity of glass-adherent cells $(p<0.001)$ (Table 4).

\section{Immunization of Rainbow Trout}

A group of rainbow trout was immunized in- 
Table 5. Protection of rainbow trout by immunization with formalin-killed Vibrio anguillarum

\begin{tabular}{|c|c|c|c|c|c|}
\hline \multirow{2}{*}{$\begin{array}{c}\text { Challenge } \\
\text { (weeks after } \\
\text { immunization) }\end{array}$} & \multirow{2}{*}{$\begin{array}{l}\text { No. survived/ } \\
\text { challenged }\end{array}$} & \multicolumn{2}{|c|}{ Suppression of bacterial growth ${ }^{11}$} & \multicolumn{2}{|c|}{ Agglutinin titer } \\
\hline & & $\begin{array}{c}\text { Before } \\
\text { challenge }\end{array}$ & $\begin{array}{l}2 \text { weeks after } \\
\text { challenge }\end{array}$ & $\begin{array}{c}\text { Before } \\
\text { challenge }\end{array}$ & $\begin{array}{l}2 \text { weeks after } \\
\text { challenge }\end{array}$ \\
\hline Unimmunized & $1 / 10$ & $191 \pm 26$ & 102 & $<2^{1.0}$ & $2^{3.0}$ \\
\hline 1 week & $7 / 10$ & $164 \pm 21$ & $104 \pm 17$ & $<2^{1.0}$ & $2^{4.7 \pm 1.8}$ \\
\hline 3 weeks & $\mathrm{NT}^{2)}$ & $121 \pm 22$ & NT & $2^{2.6 \pm 0.5}$ & NT \\
\hline 5 weeks & $8 / 8$ & $83 \pm 13$ & $94 \pm 15$ & $2^{6.4 \pm 1.2}$ & $2^{8.1 \pm 1.8}$ \\
\hline
\end{tabular}

1) Suppression of bacterial growth by antibody and complement was calculated according to the formula; $\%$ surviving bacteria $=\frac{\text { number of bacteria after incubation }}{\text { number of bacteria before incubation }} \times 100$.

2) Not tested.

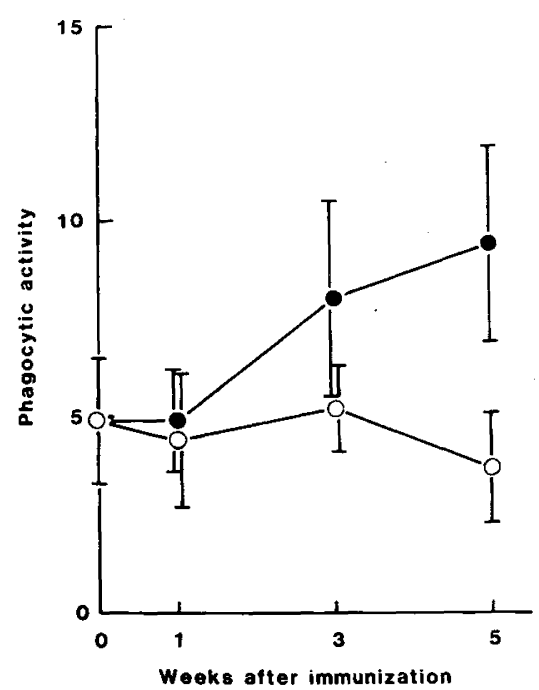

Fig. 2. Phagocytic activity of glass adherent cells immunized with formalin-killed $V$. anguillarum. Each symbol represents mean $\% \pm$ S.D. of glass adherent cells that phagocytosed more than 5 bacteria from 3 to 5 fish. To each well $2 \times 10^{7}$ cells were added. -O, immunized fish. $\mathrm{O}-\mathrm{O}$, normal fish.

traperitoneally with formalin-killed $V$. anguillarum, and the changes in the phagocytic activity of glassadherent cellis were investigated. 3.7 to $5.2 \%$ of glassadherent cells from unimmunized control fish phagocytosed more than 5 bacteria (Fig. 2). The phagocytic activity of glass-adherent cells from immunized fish increased 3 weeks after immunization and the activity was significantly higher $(p<0.02) 5$ weeks after immunization when com- pared to that of control fish.

Some fish were challenged with $V$. anguillarum for examining the condition of acquired immunity. Suppression of bacterial growth by antibody and complement in vitro was also investigated. All of the fish challenged 5 weeks after immunization survived (Table 5). These fish possessed high levels of agglutinin against $V$. anguillarum, but the bactericidal activity of the sera was not significantly high. Although 7 out of 10 fish challenged 1 week after immunization survived, the phagocytic activity of glass-adherent cells was not increased (Fig. 2) and agglutinin or bactericidal activity of the sera from these fish was not detectable. These results indicated that other unknown factor(s) might be important for resistance in the early stage of $V$. anguillarum infection.

\section{Discussion}

Though several workers have investigated phagocytosis and intracellular killing of bacteria of fish, different results have been obtained depending on the species of fish or their cells, and kinds of bacteria used in the experiments. Avtalion and SHAHRABANI (1975) found that immunization enhanced intracellular killing of Staphylococcus aureus by the cells from the whole blood of carp but the ingestion of bacteria by the cells was not influenced. GontCharov and Mikriakov (1968), however, reported in an in vivo study that phagocytosis of Aeromonas punctata, Pseudomonas fluorescens and Escherichia coli was higher in immunized carp than in nonimmunized fish. SAKAI (1984) reported that 
immunization of rainbow trout with $A$. salmonicida had no effect on the increase of phagocytosis by PEC, but he found that complement and specific antiserum dramatically accelerated the phagocytic activity. Wrathwell and PARISH (1981), however, reported that there was no difference in the in vitro clearance of yeast in plaice macrophages regardless of the presence or absence of the antiserum.

The present experiment was conducted to know the effect of specific antiserum and complement on the phagocytosis of $V$. anguillarum by cultured peritoneal macrophages from normal and immunized rainbow trout. Normal macrophages were capable of ingesting latex particles and $V$. anguillarum. The phagocytic activity against the bacteria increased when specific antiserum was added to cultures. This result is consistent with those reported by SAKaI (1984) and GrifFIN (1983) who used $A$. salmonicida and Yersinia ruckeri, respectively. Though the lack of opsonic activity of antibody has been claimed in dogfish (WRATHWELL and PARISH, 1981), the present and previous results (GrifFIN, 1983; SAKAI, 1984) indicate that at least rainbow trout antibody has opsonic activity. The present study also indicates that antibody of rainbow trout can attach not only to bacteria but also to macrophages (Table 4). Further, macrophages collected from fish immunized 5 weeks before had increased phagocytic activity in the absence of antiody and complement in the culture medium (Fig. 2). Macrophages from immune fish may bear antibodies on their surface. Thus, rainbow trout macrophages seem to possess Fc-like receptor as supposed by SAKAI (1984).

Mammalian macrophages possess complement receptors on their surface and it is considered that activated complement on bacterial surface serve as a bridge between bacteria and phagocyte and promote ingestion (DRUTZ and MiLLS, 1980). In the present study, rainbow trout complement enhanced opsonizing activity of antiserum but the complement did not increase the phagocytic activity of macrophages by itself (Fig. 1). It appears that bacteria-antibody complex activates the complement system of rainbow trout and facilitates adherence and ingestion of bacteria.

The elucidation of protective immune mechanisms in rainbow trout against $V$. anguillarum is important to understand the pathology of vibriosis. We investigated phagocytic activity of macrophage, serum antibody levels and bactericidal or bacteriostatic capacity of serum in immunized fish. Fish were completely protected when challenged 5 weeks after immunization (Table 5). At that stage, the phagocytic activity was significantly higer than that of normal fish, and immunized fish had high antibody titers (Fig. 2 and Table 5). Seven out of 10 fish also survived when challenged 1 week after immunization, although the phagocytic activity of the macrophages were just on a level with that of normal macrophages, and no antibody against $V$. anguillarum was detectable. This result indicates that phagocytosis and agglutinin may not be significant factors for resistance in an early stage of the infection. Though we did not obtain evidence in the present study that $V$. anguillarum is killed by specific antibody and complement, bacteriostatic activity was noted in serum from immunized fish or fish that survived challenge infection (Table 5). Harrell et al. (1976) reported the bactericidal activity of virulent $V$. anguillarum of immunized rainbow trout serum and mucus. An antibody-complement bactericidal system may be one of the important factors in resistance to infection with $V$. anguillarum. The activation of complement system, production of various mediators by activated lymphocytes and nonspecific immune mechanisms that occur in the early stage of the immunization should be clarified.

\section{Acknowledgements}

The authors wish to express our appreciation to Miss T. Ohmi for preparation of the manuscript. This work was supported by Grant-in-Aid for Cooperative Research from the Ministry of Education, Science and Culture of Japan.

\section{References}

ANTIPA, R. and D. F. AMEND (1977): Immunization of Pacific salmon; comparison of intraperitoneal injection and hyperosmotic infiltration of Vibrio anguillarum and Aeromonas salmonicida bacterins. J. Fish. Res. Board Can., 34, 203-208.

Avtalion, R. R. and R. Shahrabani (1975): Studies on phagocytosis in fish. I. In vitro uptake and killing of living Staphylococcus aureus by peripheral leucocytes of carp (Cyprinus carpio). Immunology, 29, 1181-1187.

Braun-Nesje, R., K. Bertheussen, G. Kaplan, and R. SELJELID (1981): Salmonid macrophages: separation, in 
vitro culture and characterization. J. Fish Dis., 4, 141151.

Drutz, D. J. and J. Mills (1980): Immunity and infection, pp. 251-273. In Fudenberg, H. H., D. F. Stites, J. L. Caldwell, and J. V. Wells (eds.), Basic and Clinical Immunology, 3rd ed., Lange Medical Publications, Los Altos.

Finn, J. P. and N. O. Nielson (1971): The inflammatory response of rainbow trout. J. Fish Biol., 3, 463-478.

Gontcharov, G. D. and V. R. Mikriakov (1968): Etude des facteurs de l'immunite des poissons a une infection bacterienne. Bull. Off. Int. Epiz., 69, 1373-1376.

GRIFFIN, B. R. (1983): Opsonic effect of rainbow trout (Salmo gairdneri) antibody on phagocytosis of Yersinia ruckeri by trout leukocytes. Develop. Comp. Immunol., 7, 253-259.

Harrell, L. W., H. M. Etlinger, and H. O. Hodgins (1976): Humoral factors important in resistance of salmonid fish to bacterial disease. II. Anti-Vibrio anguillarum activity in mucus and observation on complement. Aquaculture, 7, 363-370.

KäRBER, G. (1931): Beitrag zur kollektiven Behandlung pharmakologischen Reihenversuche. Arch. Exp. Pathol. Pharmacol., 162, 480-483.

MCKinNey, E. C., S. B. SMith, H. G. Haines, and M. M. Sigel (1977): Phagocytosis by fish cells. J. Reticuloendothel. Soc., 21, 89-95.

Miles, A. A. and S. S. Misra (1938): The estimation of the bactericidal power of the blood. J. Hyg., 38, 732-748.

SAKAI, D. K. (1981): Heat inactivation of complements and immune hemolysis reactions in rainbow trout, masu salmon, coho salmon, goldfish and tilapia. Bull. Jap. Soc. Sci. Fish., 47, 565-571.

SAKAI, D. K. (1984): Opsonization by fish antibody and complement in the immune phagocytosis by peritoneal exudate cells isolated from salmonid fishes. J. Fish Dis., 7, 29-38.

WEIR, D. M. (1973): Immunology for Undergraduates. 3rd ed., Churchill Livingstone, New York.

Wrathwell, A. B. and H. M. PARish (1981): Cell surface receptors and immune mechanisms in an elasmobranch fish Scyliorhinus canicula. pp. 463-464. In Solomon, J. B. (ed.), Aspects of Developmental and Comparative Immunology, I., Pergamon Press, Oxford. 